\title{
Identification of Physical Interaction in Binary Systems of Acyclovir - Succinic Acid
}

\author{
Agnes Nuniek Winanta ${ }^{1,2 *}$, Dwi Setyawan ${ }^{1}$, Siswandono ${ }^{1}$ \\ ${ }^{1}$ Faculty of Pharmacy Universitas Airlangga \\ ${ }^{2}$ Faculty of Pharmacy University of Surabaya \\ *Corresponding author: nuniekbening@gmail.com
}

\begin{abstract}
Background: Acyclovir, a guanosine analogue antiviral drug with low solubility of water. Due to its poor solubility and permeability, causes low oral bioavailability. Objective: The aim of this research is to investigate the physical interaction in binary systems acyclovir-succinic acid (AS). Methods: The msystem was prepared by solvent evaporation method. Results: Thermogram Differential Scanning Calorimetry showed endothermic peaks at $172.68^{\circ} \mathrm{C}$ (ethanol) and $171.84^{\circ} \mathrm{C}$ (methanol). The Powder X-Ray Diffraction (PXRD) pattern of AS was different from pure component and physical mixtures. Furthermore, physical characterization showed the binary system of AS have unique crystal habit by polarization microscope. Conclusion: New crystalline phase is formed from the interaction between acyclovir and succinic acid by solvent evaporation method using ethanol and methanol.

Keywords : physical interaction, acyclovir, succinic acid, binary systems
\end{abstract}

\begin{abstract}
Abstrak
Latar belakang: Asiklovir merupakan bahan obat antivirus analog guanosin dengan kelarutan yang rendah di dalam air. Kelarutan dan permeabilitasnya yang rendah menyebabkan bioavailabilitas oral yang juga rendah. Tujuan: tujuan penelitian ini adalah untuk menyelidiki interaksi fisika sistem biner asiklovir-asam suksinat (AS). Metode: Sistem tersebut dibuat dengan metode penguapan pelarut. Hasil: Termogram hasil penelitian menggunakan Differential Scanning Calorimetry menunjukkan puncak endotermik pada $172,68^{\circ} \mathrm{C}$ (etanol) dan $171,84^{\circ} \mathrm{C}$ (metanol). Difraktogram menggunakan Difraksi Sinar$X$ Serbuk menghasilkan pola sistem biner AS yang berbeda bila dibandingkan dengan bahan obat induk dan campuran fisik. Di samping itu, karakteristik fisik memperlihatkan bahwa sistem biner AS memiliki habit kristal yang unik melalui mikroskop polarisasi. Kesimpulan: Fase kristalin baru telah terbentuk dari hasil interaksi antara asiklovir dan asam suksinat menggunakan metode penguapan pelarut dengan etanol dan metanol.
\end{abstract}

Kata kunci : interaksi fisika, asiklovir, asam suksinat, sistem biner 


\section{INTRODUCTION}

Intermolecular interaction in binary system most likely to occur in the two materials which similar. Similarities are generally based on the molecular formula and the internal structure or level of crystallinity lattice symmetry. Interaction are often found in pharmaceutical technology including: an eutectic mixture, solid solutions (mixed crystals) and molecular compounds (cocrystals) (Sjuib \& Soewandhi, 1987; Davis et al. 2004).

Interaction between ingredients in the pharmaceutical dosage forms may cause the formation of new impurities, problems in the manufacturing process, changes in the physicochemical properties of the drug substance (such as stability, solubility, dissolution rate, degree of crystallinity and hygroscopicity) (Zalac et al., 1999).

Acyclovir (Acv), a guanosine analogue antiviral drug with a solubility of $1.62 \mathrm{mg} / \mathrm{mL}$ and $\log \mathrm{P}$ value of 1.56 , exists in six polymorphic forms, and the form $\mathrm{V}$ (ACV 2/3H2O) was selected as a commercial form. Due to its poor solubility and permeability, the bioavailability of acyclovir attains just 15-30\% (Masuda et al., 2012; Bruni et al., 2013; Yan yan et al., 2013; Sarkar \& Rohani, 2014).

This study aims to reveal acyclovir-succinic acid intermolecular interactions with microscopic identification approach using crystallization reaction. Characterization of the result of interaction was studied by crystal habit (polarized microscopy), thermal analysis (DSC), and crystallinity (PXRD).

\section{MATERIALS AND METHOD}

\section{Materials}

Acyclovir (pharmaceutical grade) commercial material was obtained from PT. Kimia Farma, Tbk., Indonesia. Succinimc acid, ethanol and methanol (pro analysis grade) were purchased from Merck Chemicals without any purification.

\section{Preparation of binary systems of AS by solvent evaporation}

Acyclovir and succinic acid carefully weighed equimolar. Each compound was dissolved in ethanol or methanol separately. The two solutions were mixed and stirred for a few minutes. Equimolar solution of both components was evaporated at room temperature for 48 hours. The obtained cocrystal solids were stored in a dessicator under vacuum (Partogi et al, 2013).

\section{Characterization by polarized microscope}

One to two mg of physical mixture between acyclovir and succinic acid was placed on object glass. A drop of ethanol was added to each physical mixture until dissolved and allowed to recrystallize. Recrystallization process was observed under a polarizing microscope. The microscopic images were recorded with an Olympus SC30 digital color camera attached to the Olympus BX-50 polarized microscope (Alatas et al., 2013).

\section{Thermal Analysis by DSC}

Differential Scanning Calorimetry (DSC) was performed using Mettler Toledo. About four mg of each sample was placed in crimped sample pan. The sample was heated from $30^{\circ}$ to $300^{\circ} \mathrm{C}$ at a heating rate of $10^{\circ} \mathrm{C} / \mathrm{min}$ under nitrogen purged (Partogi et al., 2013).

\section{Characterization by PXRD}

Powder X-ray diffraction (Phillips X'Pert diffractometer) analysis was performed at room temperature. Condition of measurement was set as follows : $\mathrm{Cu}$ metal target, $\mathrm{K} \alpha$ filter, voltage of $40 \mathrm{kV}, 40$ $\mathrm{mA}$. The analysis was performed on the range of 2 theta of $5-40^{\circ}$. Sample was placed on the sample holder and flatted to prevent particle orientation during preparation (Alatas et al., 2013).

\section{RESULTS AND DISCUSSION}

The cocrystallization process of AS binary systems was observed under polarized microscope. Polarizing light microscopy is particularly useful for studying the optical properties of crystals.

When crossed polarized light (the vibration directions of the two polarizers are oriented $90^{\circ}$ from one another) passes through an anisotropic crystal, the crystal will show bright interference colors, as long as it is not in an extinction position or aligned on an optic axis (Reutzel-Edens, 2012). As shown in Fig.1, binary systems of AS have unique crystal habit.

Differential Scanning Calorimeter (DSC) is a thermal analysis method to evaluate changes in thermodynamic properties that occur when the material supplied heat energy. Changes can be observed in the process of melting, recrystallization or solid phase 
transformations indicated by an endothermic or exothermic peaks. Figure 2 shows a new endothermic peak appears at $172.68^{\circ} \mathrm{C}$ (ethanol) and $171.84^{\circ} \mathrm{C}$ (methanol) by DSC analysis.
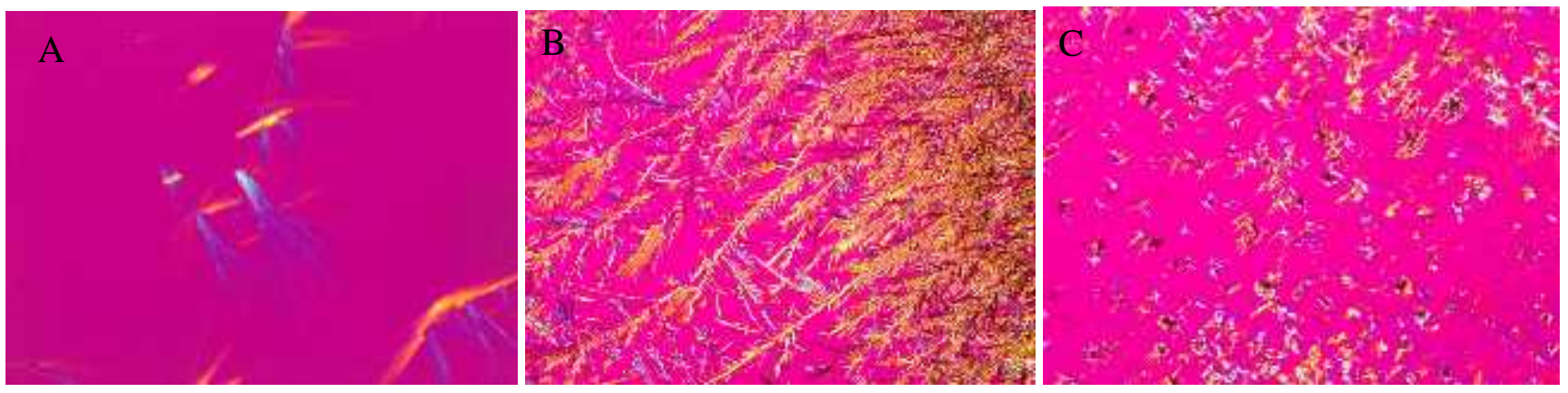

Figure 1. Photomicroscope (A) Acyclovir; (B) Succinic acid; (C) AS binary systems

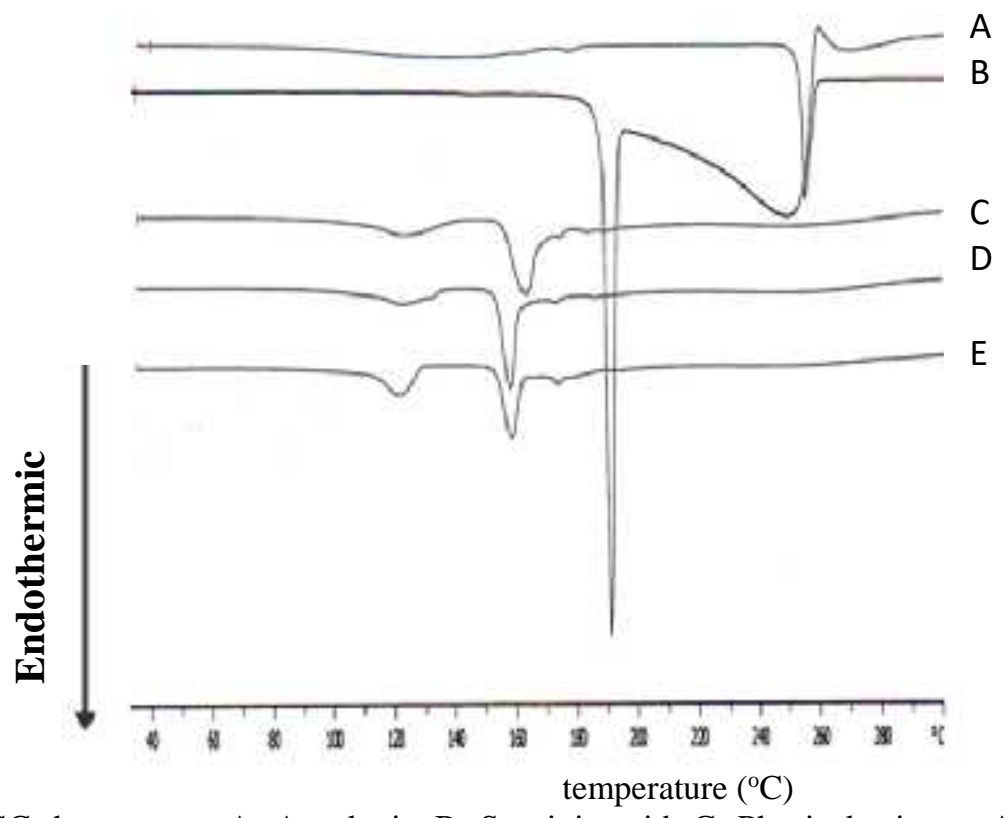

Figure 2. DSC thermogram A. Acyclovir, B. Succinic acid, C. Physical mixture AS (1:1), D. Binary systems of AS in ethanol, E. Binary systems of AS in methanol

Since every compound produces its own characteristic powder pattern owing to the unique crystallography of its structure, powder x-ray diffraction (PXRD) is clearly the most powerful and fundamental tool for a specification of the polymorphic identity of an analyte (Brittain, 1999).

New crystalline phase formed from the interaction between the two components will be observed clearly from the X-Ray Difractogram. Figure 3 and 4 shows the
X-ray powder difractogram of AS binary systems in ethanol and methanol, respectively, compared to the single component and physical mixture of both components without treatment. The PXRD pattern of AS binary systems different from the pattern of physical mixture of AS, and pure component. The PXRD pattern of binary systems showed some new interference peaks typical at $2 \theta: 5.91^{\circ} ; 9.16^{\circ}$ dan $13.40^{\circ}$ in ethanol and $2 \theta$ : $19.99^{\circ}$ dan $21.01^{\circ}$ in methanol. 


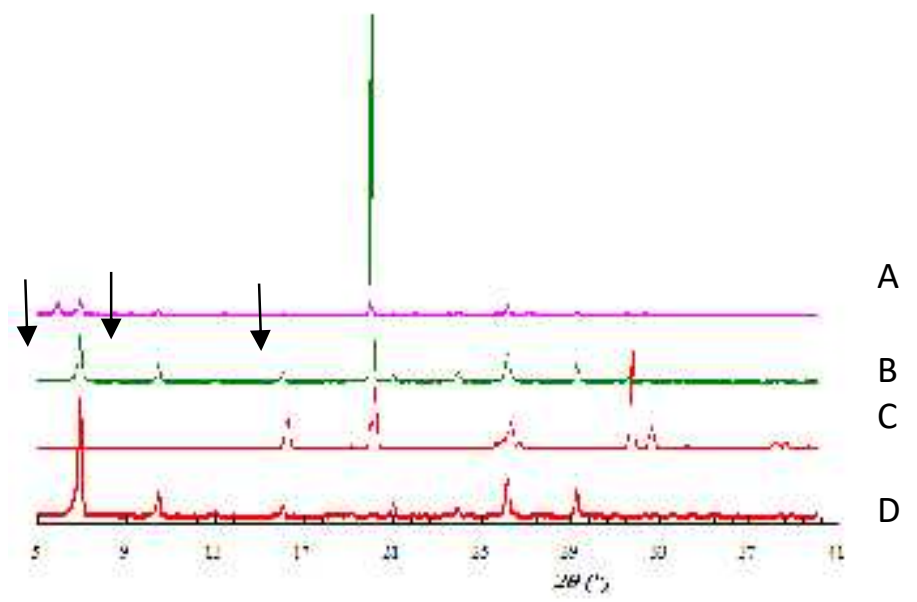

Figure 3. PXRD difractogram A. Binary systems of AS (ethanol), B. Physical mixture of AS (1:1), C. Succinic Acid, D. Acyclovir.

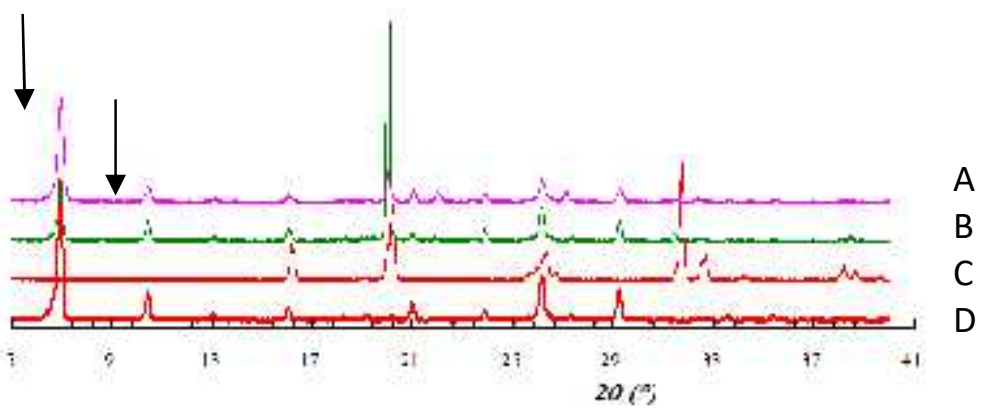

Figure 4. PXRD Difractogram A. Binary systems of AS (methanol), B. Physical mixture of AS (1:1), C. Succinic Acid, D. Acyclovir.

\section{CONCLUSION}

The results indicate that a new crystalline phase is formed from the interaction between acyclovir-succinic acid by solvent evaporation method with ethanol and methanol as solvents. It have been identified by DSC, PXRD and polarized microscope.

\section{ACKNOWLEDGEMENT}

We thank Jejen Nugraha (Plant Manager PT Kimia Farma, Tbk.) for the acyclovir commercial material.
Alatas F, Soewandhi SN, Sasongko L, Ismunandar, Uekusa H. Cocrystal formation between didanosine and two aromatic acids. International Journal of Pharmacy and Pharmaceutical Sciences 2013; 5(3): 275-80.

Brittain HG, 1999. Polymorphism in Pharmaceutical Solids. Marcel Dekker Inc., New York, 1999, p. $236 \& 256$.

Bruni G., Maietta M., Maggi L., Mustarelli P., Ferrara C., Berbenni V., Milanese C., Girella A., and Marini A., 2013. Preparation and Physicochemical Characterization of Acyclovir Cocrystals with Improved Dissolution Properties. Journal of Pharmaceutical Sciences, 102(11), 4079-4086.

\section{REFERENCES}


Davis R.E., Lorimer K.A., Wilkowski M.A., Rivers J.H., 2004, Studies of Relationship in Cocrystal Systems, ACA Transactions, 39, 41-61.

Partogi T, Soewandhi SN, Pamudji JS, Wikarsa S. 2013. Identification of physical interaction between anti malarial drugs combination artesunateamodiaquine hydrochloride. International Journal of Pharmacy and Pharmaceutical Sciences, 5(3), 206-10.

Masuda T., Yasuo Y., Etsuo Y, Kotaro F., Hidehiro U., and Katsuhide T., 2012. Cocrystallization and amorphization induced by drug-excipient interaction improves the physical properties of acyclovir. International Journal of Pharmaceutics, 422, 160-169.

Sarkar A., and Rohani, S., 2014. Cocrystal of Acyclovir with Promising Physicochemical Properties. Journal of Pharmaceutical Science, 98-105.

Sjuib F., dan Soewandhi S.N, 1987, Kimia Fisika Kristal dan Kepentingannya dalam Farmasi, Departemen Farmasi ITB.

Reutzel-Edens, S.M. 2012. Analytical Techniques and Strategies for Salt/Cocrystal Characterization. In : Wouters J \& Luc Q (ed.) Pharmaceutical Salts and Co-crystals. RSC Drug Discovery Series No.16. Royal Society of Chemistry Publishing, Cambridge, p. $217 \& 220$.

Yan yan, Jia-Mei C., and Tong-Bu L., 2013. Simultaneously Enhancing the Solubility and Permeability of Acyclovir by Crystal Engineering, Approach. CrystEngComm, 15, 6457-6460. 4

Zalac, S., Khan, M.Z., Gabelica, V., Tudja, ıvı., Mestrovic, E., dan Romih, M., 1999, ParacetamolPropyphenazone Interaction and Formulation Difficulties Associated with Eutectic Formation in Combination Solid Dosage Forms, Chemical Pharmaeutical Bulletin, 47(3), 302-307. 